\title{
Strategic supplementation of Flemingia silage to enhance rumen fermentation efficiency, microbial protein synthesis and methane mitigation in beef cattle
}

\author{
Bounnaxay Viennasay and Metha Wanapat ${ }^{*}$ (1)
}

\begin{abstract}
Background: Good quality protein as an on-farm feed resource has been in great demand to support the productivity of ruminants. A digestion trial using beef cattle crossbreds was conducted to assess the four dietary treatments of Flemingia macrophylla silage (FMS) supplementation at 0, 0.2, 0.4 and $0.6 \mathrm{~kg}$ dry matter (DM)/day in a $4 \times 4$ Latin square design. Feed DM intakes were measured during the 14 days and sample of feeds, feces, urine, as well as rumen fluid and blood were collected during the 7 days while the animals were on metabolism crates.

Results: Based on this experiment strategic supplementation of FMS increased $(P<0.05)$ nutrients digestibility (organic matter, crude protein, and acid detergent fiber) enhanced rumen total volatile fatty acid production especially propionic acid $\left(C_{3}\right), C_{2}: C_{3}$ ratio while, remarkably promoted the microbial protein synthesis (MPS) by increasing $\mathrm{N}$-balance and retention of purine derivatives.

Conclusions: Under this experiment, the results revealed the potential use of FMS as a good-quality feed to improve nutrients digestibility, rumen fermentation, microbial protein synthesis, and to mitigate methane production. FMS supplementation at $0.6 \mathrm{~kg}$ DM/day exhibited the best result.
\end{abstract}

Keywords: Fodder silage, Feed utilization, Rumen metabolism, Methane production, Phytonutrients

\section{Background}

Feed resources for ruminants are important in the livestock feeding systems for small-scale tropical farmers; particularly in the dry season [1]. Flemingia is a multipurpose legume shrub that yields fresh biomass of about 55 tons/ha/year and thrives well in diverse conditions [2]. It contains high levels of crude protein (17-26\%), condensed tannins (CT) (6-11\%) and saponins (SPN) [3-5]. The presence of these phytonutrients in feed resources has been shown to enhance the rumen fermentation efficiency and greatly reduce rumen methane

\footnotetext{
* Correspondence: metha@kku.ac.th

Tropical Feed Resources Research and Development Centre (TROFREC), Department of Animal Science, Faculty of Agriculture, Khon Kaen University, Khon Kaen 40002, Thailand
}

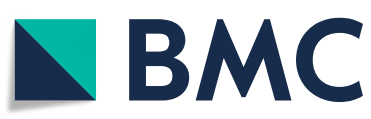

(c) The Author(s). 2020 Open Access This article is licensed under a Creative Commons Attribution 4.0 International License, which permits use, sharing, adaptation, distribution and reproduction in any medium or format, as long as you give appropriate credit to the original author(s) and the source, provide a link to the Creative Commons licence, and indicate if changes were made. The images or other third party material in this article are included in the article's Creative Commons licence, unless indicated otherwise in a credit line to the material. If material is not included in the article's Creative Commons licence and your intended use is not permitted by statutory regulation or exceeds the permitted use, you will need to obtain permission directly from the copyright holder. To view a copy of this licence, visit http://creativecommons.org/licenses/by/4.0/ The Creative Commons Public Domain Dedication waiver (http://creativecommons.org/publicdomain/zero/1.0/) applies to the data made available in this article, unless otherwise stated in a credit line to the data.
$\left(\mathrm{CH}_{4}\right)$ production [6]. Fagundes et al. [7] also reported that supplementation of Flemingia at $125 \mathrm{~g}$ of dry matter intake in goats did not affect adversely the feed intake and milk production. In addition [8], it was reported that supplemented Flemingia hay meal at $150 \mathrm{~g} / \mathrm{head} /$ day increased digestibility of nutrients, rumen fermentation and microbial protein synthesis. Moreover, Kang et al. [4] confirmed that Flemingia leaves supplementation improved rumen fermentation and reduced the $\mathrm{CH}_{4}$ production. Conservation of feed in the form of silage has been a good practice especially for dry season feeding [9]. Silage quality can be enhanced by addition of urea and molasses in fodder crop silage [10-12].

However, there is limited information about the utilization of Flemingia macrophylla silage on rumen 
fermentation. Hence, the aim of this experiment was to investigate the impact of Flemingia macrophylla silage on nutrient digestibility, rumen fermentation and microbial protein synthesis in beef cattle.

\section{Results}

Nutritive value, feed intake and nutrient digestibility

Concentrate supplement was formulated using cassava chip and agricultural by-products, namely rice bran, palm kernel meal, molasses etc., as shown in Table 1. The nutritive values of the feeds were in good ranges especially the FMS which had a good characteristic of silage both physically and chemically.

Strategic supplementation of FMS did not influence the total feed intake $(P>0.05)$, however nutrients digestibilities of DM, OM, CP, NDF, and ADF were significantly increased $(P<0.001)$ (Table 2$)$. In addition, the supplementation of FMS at $0.6 \mathrm{~kg} /$ head/day resulted in the highest in nutrients digestibilities.

\section{Rumen fermentation efficiency and blood urea nitrogen}

FMS supplementation increased total VFA and propionic acid $\left(\mathrm{C}_{3}\right) \quad(P<0.001)$, among treatments (Table 3). While the concentrations of $\mathrm{NH}_{3}-\mathrm{N}$, acetic acid $\left(\mathrm{C}_{3}\right)$, butyric acid $\left(\mathrm{C}_{4}\right)$, acetic acid to propionic acid $\left(\mathrm{C}_{2}\right.$ to $\left.\mathrm{C}_{3}\right), \mathrm{CH}_{4}$ production, and protozoal population were decreased $(P<0.001)$ among treatments, respectively. However, ruminal $\mathrm{pH}$ and $\mathrm{BUN}$ were not changed.

\section{Nitrogen balance, excretion of purine derivatives and microbial nitrogen supply}

Table 4, shows nitrogen intake ranged from $34.81 \pm 1.23$ to $48.01 \pm 2.12 \mathrm{~g} / \mathrm{d}$ and was increased $(P<0.001)$, while $\mathrm{N}$ excretion was similar among treatments $(P>0.05)$. However, $\mathrm{N}$ absorbed and $\mathrm{N}$ retained were increased $(P<0.001)$, respectively. The FMS supplementation affected on allantoin, uric acid, PD, purine absorb, microbial nitrogen supply and EMNS $(P<0.001)$. Moreover, FMS affected on percent of MNS and EMNS were increased significantly among treatments $(P<0.001)$, respectively.

\section{Discussion}

Chemical composition of feed dry matter intake and digestibility of nutrients

As shown in Table 1, the nutritive value of rice straw obtained under this experiment had a low CP content and a high level of cell wall. These findings were similar to the values by Wanapat et al. [13]. Details of rice straw

Table 1 Feed ingredients and chemical composition of experimental diets

\begin{tabular}{|c|c|c|c|}
\hline Items & Concentrate & Rice straw & Flemingia macrophylla silage (FMS) \\
\hline \multicolumn{4}{|l|}{ Ingredients (\% air-dry basis) } \\
\hline Cassava chip & 60.00 & 0.00 & 0.00 \\
\hline Brewery's grain, dried & 12.00 & 0.00 & 0.00 \\
\hline Rice bran & 9.00 & 0.00 & 0.00 \\
\hline Palm kernel meal & 13.00 & 0.00 & 0.00 \\
\hline Urea & 2.00 & 0.00 & 0.00 \\
\hline Molasses & 2.00 & 0.00 & 0.00 \\
\hline Sulfur & 0.50 & 0.00 & 0.00 \\
\hline Salt & 1.00 & 0.00 & 0.00 \\
\hline Mineral premix & 0.50 & 0.00 & 0.00 \\
\hline \multicolumn{4}{|c|}{ Chemical composition (\% DM) } \\
\hline Dry matter & 87.50 & 90.00 & 26.50 \\
\hline Organic matter & 14.80 & 2.80 & 18.10 \\
\hline Crude protein & 94.20 & 96.40 & 95.60 \\
\hline Neutral detergent fiber & 28.90 & 71.70 & 47.50 \\
\hline Acid detergent fiber & 17.20 & 47.70 & 37.20 \\
\hline Condensed tannins & 0.00 & 0.00 & 10.20 \\
\hline $\mathrm{pH}$ & 0.00 & 0.00 & 4.40 \\
\hline Lactic acid (g/L) & 0.00 & 0.00 & 2.00 \\
\hline Acetic acid (g/L) & 0.00 & 0.00 & 0.50 \\
\hline
\end{tabular}


Table 2 Effect of Flemingia macrophylla silage (FMS) on feed intake and nutrients digestibility

\begin{tabular}{|c|c|c|c|c|c|c|}
\hline \multirow[t]{2}{*}{ Items } & \multicolumn{4}{|c|}{ FMS kg/d of dry mater } & \multirow[t]{2}{*}{ SEM } & \multirow[t]{2}{*}{$P$-value } \\
\hline & 0 & 0.2 & 0.4 & 0.6 & & \\
\hline \multicolumn{7}{|l|}{ Roughage Intake (DM basis) } \\
\hline $\mathrm{Kg} / \mathrm{d}$ & $3.13 \pm 0.84$ & $3.23 \pm 0.97$ & $3.40 \pm 0.89$ & $3.58 \pm 0.70$ & 1.00 & 0.47 \\
\hline Body weight (\%) & $1.81 \pm 0.25$ & $1.97 \pm 0.22$ & $1.89 \pm 0.34$ & $2.14 \pm 0.11$ & 0.60 & 0.44 \\
\hline \multicolumn{7}{|l|}{ Concentrate Intake } \\
\hline $\mathrm{kg} / \mathrm{d}$ & $0.90 \pm 0.17$ & $0.90 \pm 0.17$ & $0.90 \pm 0.17$ & $0.90 \pm 0.17$ & 0.00 & 0.00 \\
\hline Body weight (\%) & $0.50 \pm 0.03$ & $0.50 \pm 0.03$ & $0.50 \pm 0.03$ & $0.50 \pm 0.03$ & 0.00 & 0.00 \\
\hline \multicolumn{7}{|l|}{ Total Intake } \\
\hline $\mathrm{Kg} / \mathrm{d}$ & $4.00 \pm 0.98$ & $4.30 \pm 1.13$ & $4.10 \pm 1.03$ & $4.50 \pm 0.85$ & 1.00 & 0.48 \\
\hline Body weight (\%) & $2.32 \pm 0.24$ & $2.48 \pm 0.22$ & $2.41 \pm 0.35$ & $2.60 \pm 0.21$ & 0.06 & 0.44 \\
\hline \multicolumn{7}{|l|}{ Digestibility (\%) } \\
\hline Dry matter & $54.11 \pm 1.49^{\mathrm{a}}$ & $58.61 \pm 0.68^{b}$ & $62.30 \pm 2.57^{c}$ & $63.62 \pm 2.49^{c}$ & 0.21 & 0.001 \\
\hline Organic matter & $58.20 \pm 0.46^{\mathrm{a}}$ & $64.40 \pm 0.42^{b}$ & $68.40 \pm 2.10^{c}$ & $71.45 \pm 0.66^{d}$ & 0.29 & 0.001 \\
\hline Crude protein & $53.80 \pm 0.65^{\mathrm{a}}$ & $55.60 \pm 0.32^{\mathrm{b}}$ & $57.10 \pm 0.17^{c}$ & $58.70 \pm 0.32^{d}$ & 0.10 & 0.001 \\
\hline Neutral detergent fiber & $50.00 \pm 0.81^{\mathrm{a}}$ & $51.90 \pm 0.92^{\mathrm{ab}}$ & $54.00 \pm 0.56^{\mathrm{ab}}$ & $55.40 \pm 1.89^{c}$ & 0.12 & 0.05 \\
\hline Acid detergent fiber & $45.80 \pm 0.28^{a}$ & $47.30 \pm 0.54^{b}$ & $49.60 \pm 0.88^{c}$ & $52.80 \pm 0.54^{d}$ & 0.15 & 0.001 \\
\hline
\end{tabular}

$\overline{\mathrm{a}, \mathrm{b}, \mathrm{c}, \mathrm{d}}$ Means in the same row with different superscripts differ $(P<0.01)$, SEM Standard error of the mean

and the enhancement of nutritive value by various treatments had been illustrated by Wanapat et al. [14]. Flemingia is the shrub which can produce biomass for ruminant feeding. It contains high level of crude protein, CT and SP. The feed can be ensiled as silage for long time feeding, details are shown in Table 1, FMS contains $18.10 \% \mathrm{CP}, 95.60 \% \mathrm{OM}, 47.50 \% \mathrm{NDF}, 37.20 \% \mathrm{ADF}$, and $10.20 \% \mathrm{CT}$, with $\mathrm{pH}$ of 4.4 and good characteristics. As reported by [15-17] who indicated that the $\mathrm{pH}$ of good silage should be 3.5 to 4.5 . These results have shown that FMS was a good alternative feed to improve the quality and for a long dry season feeding. Providing additional source of energy such as molasses and urea as a non-protein nitrogen will lead to a higher $\mathrm{CP}$ content of the silage [18]. Feeding this silage with higher CP content would enrich the overall utilization especially when fed with low-quality roughages. Under this study, there were no differences in DM intakes among treatments $(P<0.05)$, but enhanced the digestibilities of $\mathrm{OM}, \mathrm{CP}$, NDF and ADF. Higher level of CP of the silage could have attributed the degradation activity of the rumen microbiomes. Phesatcha et al. [8] found similar results. It has been reported that $\mathrm{CT}$ in the feeds combined with protein to protect protein degradability in the rumen

Table 3 Effect of Flemingia macrophylla silage (FMS) on rumen ecology and fermentation

\begin{tabular}{|c|c|c|c|c|c|c|}
\hline \multirow[t]{2}{*}{ Items } & \multicolumn{4}{|c|}{ FMS kg/d of dry mater } & \multirow[t]{2}{*}{ SEM } & \multirow[t]{2}{*}{$P$-value } \\
\hline & 0 & 0.2 & 0.4 & 0.6 & & \\
\hline $\mathrm{NH}_{3}-\mathrm{N}(\mathrm{mg} / \mathrm{ml})$ & $19.31 \pm 0.12^{d}$ & $18.32 \pm 0.13^{c}$ & $17.53 \pm 0.11^{b}$ & $16.91 \pm 0.08^{a}$ & 0.50 & 0.001 \\
\hline BUN (mg/dl) & $10.11 \pm 0.13$ & $10.03 \pm 0.21$ & $10.21 \pm 0.43$ & $10.03 \pm 0.38$ & 0.02 & 0.83 \\
\hline Total VFA (mM/L) & $99.50 \pm 4.61^{\mathrm{a}}$ & $102.90 \pm 4.61^{\mathrm{ab}}$ & $107.70 \pm 3.52^{b c}$ & $112.50 \pm 4.23^{c}$ & 2.82 & 0.004 \\
\hline \multicolumn{7}{|l|}{ VFA (mol/100 mol) } \\
\hline Acetic acid & $73.90 \pm 0.67^{d}$ & $73.00 \pm 0.36^{c}$ & $71.70 \pm 0.94^{b}$ & $70.20 \pm 0.98^{\mathrm{a}}$ & 0.81 & 0.001 \\
\hline Propionic acid & $16.50 \pm 0.20^{\mathrm{a}}$ & $17.70 \pm 0.19^{b}$ & $19.30 \pm 0.59^{c}$ & $20.90 \pm 0.74^{d}$ & 0.95 & 0.001 \\
\hline Butyric acid & $9.70 \pm 0.53^{c}$ & $9.20 \pm 0.33^{b}$ & $9.00 \pm 0.39^{\mathrm{ab}}$ & $8.90 \pm 0.26^{\mathrm{a}}$ & 0.18 & 0.002 \\
\hline Acetic acid to Propionic acid & $4.50 \pm 0.08^{d}$ & $4.10 \pm 0.06^{c}$ & $3.80 \pm 0.16^{\mathrm{b}}$ & $3.40 \pm 0.16^{\mathrm{a}}$ & 0.23 & 0.001 \\
\hline Methane (mol/100 mol) & $32.60 \pm 0.16^{d}$ & $31.68 \pm 0.14^{c}$ & $30.59 \pm 0.45^{b}$ & $29.38 \pm 0.55^{a}$ & 0.69 & 0.001 \\
\hline $\mathrm{pH}$ & $6.82 \pm 0.03$ & $6.87 \pm 0.02$ & $6.84 \pm 0.03$ & $6.89 \pm 0.02$ & 0.02 & 0.13 \\
\hline Protozoa $\left(\times 10^{5} \mathrm{Cell} / \mathrm{ml}\right)$ & $8.08 \pm 0.07^{c}$ & $6.65 \pm 0.05^{b}$ & $4.98 \pm 0.07^{\mathrm{a}}$ & $4.40 \pm 0.09^{\mathrm{a}}$ & 0.83 & 0.009 \\
\hline
\end{tabular}

$\overline{\mathrm{a}, \mathrm{b}, \mathrm{c}, \mathrm{d}}$ Means in the same row with different superscripts differ $(P<0.01)$, SEM Standard error of the mean, BUN Blood urea nitrogen, VFA Volatile fatty acid, Methane production $=0.45$ (acetic acid) -0.275 (propionic acid) +0.4 (butyric acid) 
Table 4 Effects of Flemingia macrophylla silage (FMS) on nitrogen balance, excretion of purine derivatives and microbial nitrogen supply

\begin{tabular}{|c|c|c|c|c|c|c|}
\hline \multirow[t]{2}{*}{ Items } & \multicolumn{4}{|c|}{ FMS $\mathrm{kg} / \mathrm{d}$ of dry mater } & \multirow[t]{2}{*}{ SEM } & \multirow{2}{*}{$\begin{array}{l}P \text { - } \\
\text { value }\end{array}$} \\
\hline & 0 & 0.2 & 0.4 & 0.6 & & \\
\hline \multicolumn{7}{|l|}{ Nitrogen utilization (g/d) } \\
\hline Intake & $34.81 \pm 1.23^{\mathrm{a}}$ & $41.02 \pm 1.54^{b}$ & $44.03 \pm 1.98^{c}$ & $48.01 \pm 2.12^{d}$ & 2.79 & 0.001 \\
\hline \multicolumn{7}{|l|}{$N$ excretion $(\mathrm{g} / \mathrm{d})$} \\
\hline Fecal N & $15.20 \pm 2.32$ & $16.00 \pm 1.98$ & $16.20 \pm 1.67$ & $13.90 \pm 1.59$ & 0.52 & 0.54 \\
\hline Urinal N & $13.00 \pm 1.41$ & $13.40 \pm 1.50$ & $11.80 \pm 1.83$ & $10.50 \pm 1.92$ & 0.65 & 0.25 \\
\hline \multicolumn{7}{|l|}{$\mathrm{N}$ balance $(\mathrm{g} / \mathrm{d})$} \\
\hline Absorbed N & $19.61 \pm 1.04^{\mathrm{a}}$ & $25.02 \pm 1.67^{b}$ & $28.01 \pm 1.91^{b}$ & $34.10 \pm 1.98^{c}$ & 3.02 & 0.001 \\
\hline Retained N & $6.70 \pm 0.54^{\mathrm{a}}$ & $11.61 \pm 0.946^{b}$ & $17.63 \pm 1.32^{c}$ & $22.30 \pm 1.27^{d}$ & 3.41 & 0.001 \\
\hline Allantoin (mM/d) & $108.92 \pm 3.54^{a}$ & $122.61 \pm 4.21^{b}$ & $130.67 \pm 5.33^{b}$ & $148.71 \pm 8.12^{c}$ & 8.30 & 0.001 \\
\hline Uric acid (mM/d) & $26.11 \pm 1.34^{\mathrm{a}}$ & $29.42 \pm 2.30^{b}$ & $31.33 \pm 1.11^{b}$ & $35.56 \pm 1.72^{c}$ & 1.99 & 0.001 \\
\hline $\mathrm{PD}(\mathrm{mM} / \mathrm{d})$ & $130.67 \pm 3.43^{a}$ & $147.22 \pm 2.31^{b}$ & $156.78 \pm 3.16^{b}$ & $178.43 \pm 2.81^{c}$ & 9.96 & 0.001 \\
\hline Purine absorb $(\mathrm{mM} / \mathrm{d})$ & $109.3 \pm 2.43^{\mathrm{a}}$ & $125.7 \pm 2.56^{b}$ & $135.4 \pm 2.11^{\mathrm{b}}$ & $157.0 \pm 2.43^{c}$ & 9.96 & 0.001 \\
\hline MNS (g N/d) & $79.41 \pm 2.21^{\mathrm{a}}$ & $91.4 \pm 3.11^{\mathrm{b}}$ & $98.4 \pm 4.01^{b}$ & $114.1 \pm 4.87^{c}$ & 7.24 & 0.001 \\
\hline MNS increased (\%) & $0.00 \pm 0.00^{a}$ & $15.43 \pm 1.65^{b}$ & $24.12 \pm 1.93^{b}$ & $44.01 \pm 2.88^{c}$ & 9.20 & 0.002 \\
\hline EMNS (g N/kg OMDR) & $9.60 \pm 0.13^{a}$ & $11.31 \pm 0.46^{\mathrm{b}}$ & $14.13 \pm 0.72^{c}$ & $14.12 \pm 0.54^{c}$ & 1.01 & 0.003 \\
\hline EMNS increased (\%) & $0.00 \pm 0.00^{a}$ & $18.92 \pm 1.63^{b}$ & $39.78 \pm 1.97^{b}$ & $49.01 \pm 2.41^{c}$ & 10.9 & 0.001 \\
\hline
\end{tabular}

a,b,c Means in the same row with different superscripts differ $(P<0.05)$, SEM Standard error of the mean, $N$ Nitrogen, MNS Microbial nitrogen supply, $P D$ Purine derivatives. Microbial N $(\mathrm{g} \mathrm{N} / \mathrm{d})=(\mathrm{X} \times 70) /(0.116 \times 0.83 \times 1,000)=0.727 \times X$ (where, $X=$ total absorption of purine derivatives). EMNS $=$ Efficiency of microbial nitrogen supply (g N/kg OMDR). OMDR $(\mathrm{kg})=65 \%$ of organic matter digestible in total tract

[19]. Tannin-protein feed complex would be available more in the lower-gut.

\section{Rumen Volatile Fatty Acids (VFA) and Blood-Urea- Nitrogen (BUN)}

Ruminal $\mathrm{pH}$ and BUN were not significantly shifted differently among treatments. This result was similar to the findings of Phesatcha et al. [8] who reported Flemingia leaf supplementation did not change ruminal $\mathrm{pH}$ and BUN. The normal rumen $\mathrm{pH}$ was reported to be 6.3-6.8 which can support cellulolytic bacteria's normal activity [20]. The tannin-protein complex in rumen could result in lower rumen $\mathrm{NH}_{3}-\mathrm{N}$ and enhance the protein availability in lower-gut [21, 22]. Ruminal $\mathrm{NH}_{3}-\mathrm{N}$ concentration was a key factor (15$30 \mathrm{mg} / \mathrm{ml}$ ) for efficient microbial protein synthesis [23]. In this study, the ruminal $\mathrm{NH}_{3}-\mathrm{N}$ values (16.91 \pm 0.08 to $19.31 \pm 0.12 \mathrm{mg} / \mathrm{ml}$ ) were found and could improve for rumen ecology in cattle crossbreds. With increased levels of FMS supplementation, the total VFA and $C_{3}$ were remarkably increased $(P<0.05)$, and the highest impact was found in the group fed with of $0.6 \mathrm{~kg} /$ day, while $C_{2}, C_{2}$ to $C_{3}$ ratio were reduced. Under the work of Phesatcha et al. [8], it was revealed that the ruminal $C_{2}$ was reduced, which $C_{3}$ was increased $(P<0.05)$. Makkar et al. [24] further showed that feeds containing condensed tannins (CT) could lower the ruminal $\mathrm{C}_{2}$ concentration. It was additionally reported that CT can impact on methanogenesis by reducing protozoa and methanogens, when $\mathrm{C}_{2}$ was reduced but $\mathrm{C}_{3}$ was greatly enhanced [25]. Another possible influence of rumen $\mathrm{CH}_{4}$ depression could be influenced by the suppression of protozoal population by FMS supplementation. This may be attributed to CT in FMS which could interfere the cell membrane of protozoa, thus interfering with ion exchanges [26]. Poungchompu et al. [27] earlier reported that dairy heifer crossbreds supplemented with feeds containing phytonutrients had reduced protozoal count. The population of rumen protozoal and methane emission were significantly reduced [28]. Earlier reports revealed that supplementation of plant secondary compounds, especially condensed tannins and saponins, could remarkably reduce protozoal population and methanogens in ruminants. However, the effect depended on dose-response of $1-2 \%$ of dry matter intake. Possible modes of action could be due to the direct effect of tannins on physical coating of protozoa whilst, saponins formed the sterol-biding with cell membrane of protozoa causing the destruction and blockage of ion-exchanges. Hence, such phenomenon caused the lysis of protozoa and methanogens [29-31]. However, in another study, it was shown that PTN could increase the population of Fibrobacter succinogenes, while the other two fibrolytic bacteria; Ruminococcus albus and Ruminococcus 
flavefaciens were decreased, but the actual mode of action needs to be further elucidated [32].

\section{Nitrogen balance, excretion of purine derivatives and microbial protein synthesis}

FMS supplementation affected N-balance as shown in Table 4. The N-absorbed and retention were linearly increased with FMS supplementation due to $\mathrm{N}$-intake and $\mathrm{CP}$ digestibility, however $\mathrm{N}$-excretion of fecal and urine were similar among treatments. Agreed with, Viennasay et al. [12] who showed that the N-balance was improve when the digestibility of $\mathrm{CP}$ was high. In addition, rumen tannin-protein complex can support more protein available in lower-gut [33]. As shown, microbial protein synthesis in the rumen was a good indicator for efficient protein synthesis to enhance the overall protein utilization by the host ruminants [34]. Ruminal $\mathrm{NH}_{3}-\mathrm{N}$ concentration has been shown to support the microbial protein synthesis, as it was well-utilized by cellulolytic bacteria as an important source of nitrogen [35]. In adequate doses, the efficiency in microbial synthesis and the microbial yield were increased by including saponins [36] or CT [37] in the diets. Under this study, supplementation of FMS containing both CT and SPN, could provide additional protein available at the lower-gut for the host ruminants, as well as enhancing rumen fermentation efficiency.

\section{Conclusions}

Under this experiment, the results revealed the potential use of Flemingia macrophylla silage as a good-quality feed to improve nutrients digestibility, rumen fermentation, microbial protein synthesis, and to mitigate methane production. Flemingia macrophylla silage supplementation at $0.6 \mathrm{~kg} \mathrm{DM} /$ day exhibited the best result. Making Flemingia macrophylla silage should be encouraged to prepare for on-farm use especially during the long dry season. Furthermore, in vivo feeding trials should be conducted in both beef cattle and dairy cattle in order to obtain more relevant data.

\section{Methods}

This experiment approval was granted by the Institutional Animal Care and Use Committee of Khon Kaen University, Thailand (Record no. IACUC-KKU-94/61 and reference no. 0201.2. 11/73).

\section{Preparation of Flemingia macrophylla silage}

Flemingia macrophylla was planted by stems on the experimental plots of Tropical Feed Resources Research and Development Center (TROFREC), Department of Animal Science, Faculty of Agriculture, Khon Kaen University, Thailand with close supervision of the advisory Professor. All plant parts were kept and stored at
TROFREC. Flemingia macrophylla (FM) whole top plant was harvested from the shrub after three months of regrowth. Silage of Flemingia was prepared by using young-whole leaf and stem, chopped $(3 \mathrm{~cm})$ and mixed with solution. Chopped fresh Flemingia (100 kg) was well-mixed with solution containing molasses, urea and water at 2:1:10, respectively. The mixture was ensiled in a plastic barrel for 21 days before feeding. Samples of FMS was randomly collected and later was analyzed for chemical compositions [38, 39], condensed tannins by methods [40, 41]. Apart from that, a FMS sample was washed with deionizing water for analyzed lactic acid and acetic acid analysis [42].

\section{Sample size}

The sample size calculation was based on experimental design according to in a $4 \times 4$ Latin square design with 4 replicates, which provided a total of 16 experimental units.

\section{Inclusion and exclusion criteria}

Neither inclusion nor exclusion was used, since the four beef cattle were similar in age, weight and pre-fed under similar feeding condition.

\section{Blinding}

No blinding was performed, as the four treatments were already randomized statistically.

\section{Animals and design}

These experimental beef crossbreds belonged to Tropical Feed Resource Research and Development center (TROFREC), Khon Kaen University and were provided as experimental animals for Ph.D. students. The animals were well-maintained for their health with good feeding and other management. After the experiment all animals were kept and maintained well with all aspects; health, nutrition, feeding and would be used later for other experiments. Four, beef cattle about two year old with $172 \pm 43 \mathrm{~kg}$ liveweight, were randomly assigned to in a $4 \times 4$ Latin square design. Concentrate was offered at $0.5 \mathrm{~kg}$ of body weight $(\mathrm{BW}) /$ day and rice straw offered ad libitum with supplementation of FMS at 0, 0.2, 0.4 and $0.6 \mathrm{~kg} \mathrm{DM} / \mathrm{head} /$ day. The trial was conducted for four periods each was consisted of 21 days, during the first 14 days was for matter feed intake measurement, while during the last 7 days for sample collection using total collection method. Each animal was in individual pens, where clean water and mineral-salt blocks were available at all times. The diet was offered to the animals twice dairy in the morning (07:00a.m.) and afternoon (04.00p.m.). The liveweight of each cattle was weighed at the beginning and the end of each period to calculate feed intake. Feed provided and refusals were measured 
daily throughout the experimental period. Feed samples were collected twice a week for DM analysis. Samples of feeds including concentrate, FMS, rice straw, feces were collected randomly daily during the last 7 days of each period. A daily sample of feces of each animal (about $100 \mathrm{~g}$ ) was collected to be analyses [38]. Urinary samples were collected and prepared for storage and later analyzed for total nitrogen [38], and total purine derivatives and calculation of microbial $\mathrm{N}$ supply (MNS) [43, 44]. Details of sampling procedures of rumen fluid from each animal analysis of volatile fatty acids (VFA) [42], protozoal population count [45], and estimated methane $\left(\mathrm{CH}_{4}\right)$ production [46] are presented in details in Wanapat et al. [47]. Blood samples (about $10 \mathrm{ml}$ ) were collected from the jugular vein at each rumen sampling time and kept in the tubes to which $0.1 \mathrm{~g}$ EDTA was added for analysis of blood urea-nitrogen (BUN) [48].

\section{Data management and statistical analysis}

The samples were estimated according to the statistical design used $4 \times 4$ Latin Square Design.

All data were included in all analysis subjected to ANOVA according to a $4 \times 4$ Latin square design using the General Linear Models (GLM) procedures [49]. The results were presented as mean values with the standard error of the means. Difference among means with $P<0.05$ was accepted as statistical differences while $0.05<P<0.10$ was accepted as a tendency. Treatment means were statistically compared by Duncan's New Multiple Range Test [50].

\section{Abbreviations}

ADF: Acid detergent fiber; BUN: Blood urea nitrogen; BW: Body weight; $C$ : Concentrate; $C$ : Crude protein; $C_{2}$ : Acetate; $C_{3}$ : Propionate; $C_{4}$ : Butyrate; CP: Condensed tannins; DM: Dry matter; EMNS: Efficiency of microbial nitrogen supply; FMS: Flemingia macrophylla silage; NDF: Neutral detergent fiber; $\mathrm{NH}_{3}-\mathrm{N}$ : Ammonia-nitrogen; N: Nitrogen; MNS: Microbial nitrogen supply;i OM: Organic matter; PD: Purine derivatives; SP: Saponins; VFA: Volatile fatty acid

\section{Acknowledgements}

The technical support rendered by Animal Nutrition Research Institute, Department of Livestock Development-Thapra, Dairy Production Organization of Thailand, Northeast (DPO-NE), are greatly acknowledged.

\section{Authors' contributions}

BV was the main researcher who conducted most of the research activities. BV and MW designed the experiments. BV conducted the animal experiments. BV performed the analyses. BV and MW wrote the manuscript. All authors reviewed and contributed to the manuscript. MW revised the final draft of manuscript. All authors read and approved the final manuscript.

\section{Funding}

This research was supported by Tropical Feed Resources Research and Development Center (TROFREC), Department of Animal Science, Faculty of Agriculture, Khon Kaen University. Thailand Research Fund and International Research Network (TRF-IRN) TRF-IRN57W0002. KKU Scholarship for ASEAN and GMS Countries' Personnel. The Funding donors did not have roles in the design of the study; research conduct, samples collection, analysis, and interpretation of data; and in writing the manuscript.
Availability of data and materials

All experimental data are responsible and available under the holding of the corresponding author.

\section{Ethics approval and consent to participate}

The experiment was officially agreed and approved by the Khon Kaen University Committee of Animal Care and Use for Research. The experimental cattle were provided by our research farm (TROFREC, KKU).

\section{Consent for publication}

Not applicable.

\section{Competing interests}

The authors declare that they have no competing interests.

Received: 24 April 2020 Accepted: 2 December 2020

Published online: 09 December 2020

\section{References}

1. Wanapat M. The role of cassava hay as animal feed. DOA CIAT 504. 2002.

2. Binh DV, Tien NP, Mui NT. Study on biomass yield and quality of Flemingia macrophylla and on soil fertility. In Proc. Workshop Anim Nutr Sci. 1998;137.

3. Andersson MS, Lascano CE, Schultze-Kraft R, Peters M. Forage quality and tannin concentration and composition of a collection of the tropical shrub legume Flemingia macrophylla. J Sci Food Agric. 2006;86:1023-31.

4. Tiemann TT, Lascano CE, Wettstein HR, Mayer AC, Kreuzer M, Hess HD. Effect of the tropical tannin-rich shrub legumes Calliandra calothyrsus and Flemingia macrophylla on methane emission and nitrogen and energy balance in growing lambs. Anim. 2008;2:790-9.

5. Kang S, Wanapat M, Phesatcha K, Norrapoke T, Foiklang S, Ampapon T, Phesatcha B. Using krabok (Irvingia malayana) seed oil and Flemingia macrophylla leaf meal as a rumen enhancer in an in vitro gas production system. Anim Prod Sci. 2017:57:327-33.

6. Williams CM, Eun JS, MacAdam JW, Young AJ, Fellner V, Min BR. Effects of forage legumes containing condensed tannins on methane and ammonia production in continuous cultures of mixed ruminal microorganisms. Anim Feed Sci Technol. 2011;166:364-72.

7. Fagundes GM, Modesto EC, Fonseca CEM, Lima HRP, Muir JP. Intake, digestibility and milk yield in goats fed Flemingia macrophylla with or without polyethylene glycol. Small Ruminant Res. 2014;116:88-93.

8. Phesatcha B, Wanapat M, Phesatcha K, Ampapon T, Kang S. Supplementation of Flemingia macrophylla and cassava foliage as a rumen enhancer on fermentation efficiency and estimated methane production in dairy steers. Trop Anim Health Prod. 2016;48:1449-54.

9. Cheli F, Campagnoli A, Dell'Orto V. Fungal populations and mycotoxins in silages: From occurrence to analysis. Anim Feed Sci Technol. 2013;183:1-16.

10. Wanapat M, Phesatcha K, Viennasay B, Phesatcha B, Ampapon T, Kang S. Strategic supplementation of cassava top silage to enhance rumen fermentation and milk production in lactating dairy cows in the tropics. Trop Anim Health Prod. 2018:50:1539-46.

11. Giang NTT, Wanapat M, Phesatcha K, Kang S. Level of Leucaena leucocephala silage feeding on intake, rumen fermentation, and nutrient digestibility in dairy steers. Trop Anim Health Prod. 2016:48:1057-64.

12. Viennasay B, Wanapat $M$, Phesatcha K, Phesatcha B, Ampapon T. Replacement of rice straw with cassava-top silage on rumen ecology, fermentation and nutrient digestibilities in dairy steers. Anim Prod Sci. 2019; 59:906-13.

13. Wanapat M, Polyorach S, Boonnop K, Mapato C, Cherdthong A. Effects of treating rice straw with urea or urea and calcium hydroxide upon intake, digestibility, rumen fermentation and milk yield of dairy cows. Livest Sci. 2009;125:238-43.

14. Wanapat M, Sundstøl F, Garmo TH. A comparison of alkali treatment methods to improve the nutritive value of straw. I. Digestibility and metabolizability. Anim Feed Sci Technol. 1985:12:295-309.

15. Carpintero CM, Henderson AR, McDonald P. The effect of some pretreatments on proteolysis during the ensiling of herbage. Grass Forage Sci. 1979;34:311-5.

16. Man NV, Wiktorsson $\mathrm{H}$. Effect of molasses on nutritional quality of cassava and gliricidia tops silage. Asian-Australas J Anim Sci. 2002;15:1294-9.

17. Ali M, Cone JW, Van Duinkerken G, Klop A, Blok MC, Bruinenberg M, Khan NA, Hendriks WH. Variation between individual cows in in situ rumen 
degradation characteristics of maize and grass silages. NJAS-NJAS-Wagen $J$ Life Sci. 2016;78:167-73.

18. Staples CR, Fahey GC Jr, Rindsig RB, Berger LL. Evaluation of dairy waste fiber as a roughage source for ruminants. J Dairy Sci. 1981;64:662-71.

19. Wanapat M, Pilajun R, Polyorach S, Cherdthong A, Khejornsart P, Rowlinson P. Effect of carbohydrate source and cottonseed meal level in the concentrate on feed intake, nutrient digestibility, rumen fermentation and microbial protein synthesis in swamp buffaloes. Asian-Australas J Anim Sci. 2013;26:952.

20. Calabrò S, Cutrignelli MI, Piccolo G, Bovera F, Zicarelli F, Gazaneo MP, Infascelli F. In vitro fermentation kinetics of fresh and dried silage. Anim Feed Sci Technol. 2005;123:129-37.

21. Hess HD, Mera ML, Tiemann TT, Lascano CE, Kreuzer M. In vitro assessment of the suitability of replacing the low-tannin legume Vigna unguiculata with the tanniniferous legumes Leucaena leucocephala, Flemingia macrophylla or Calliandra calothyrsus in a tropical grass diet. Anim Feed Sci Technol. 2008; 147:105-15.

22. Hassanat $F$, Benchaar $C$. Assessment of the effect of condensed (acacia and quebracho) and hydrolysable (chestnut and valonea) tannins on rumen fermentation and methane production in vitro. J Sci Food Agric. 2013;93: 332-9.

23. Wanapat $\mathrm{M}$, Pimpa O. Effect of ruminal $\mathrm{NH}_{3}-\mathrm{N}$ levels on ruminal fermentation, purine derivatives, digestibility and rice straw intake in swamp buffaloes. Asian-Australas J Anim Sci. 1999;12:904-7.

24. Makkar HP, Becker K, Abel HJ, Szegletti C. Degradation of condensed tannins by rumen microbes exposed to quebracho tannins (QT) in rumen simulation technique (RUSITEC) and effects of QT on fermentative processes in the RUSITEC. J Sci Food Agric. 1995;69:495-500.

25. Dschaak CM, Williams CM, Holt MS, Eun JS, Young AJ, Min BR. Effects of supplementing condensed tannin extract on intake, digestion, ruminal fermentation, and milk production of lactating dairy cows. J Dairy Sci. 2011; 94:2508-19.

26. Klita PT, Mathison GW, Fenton TW, Hardin RT. Effects of alfalfa root saponins on digestive function in sheep. J Anim Sci. 1996;74:1144-56.

27. Poungchompu O, Wanapat M, Wachirapakorn C, Wanapat S, Cherdthong A. Manipulation of ruminal fermentation and methane production by dietary saponins and tannins from mangosteen peel and soapberry fruit. Arch Anim Nutr. 2009;63:389-400.

28. Patra AK, Saxena J. Exploitation of dietary tannins to improve rumen metabolism and ruminant nutrition. J Sci Food Agric. 2011;91:24-37.

29. Wallace RJ. Antimicrobial properties of plant secondary metabolites. Proc Nutr Soc. 2004:63:621-9.

30. Hart KJ, Yáñez-Ruiz DR, Duval SM, McEwan NR, Newbold CJ. Plant extracts to manipulate rumen fermentation. Anim Feed Sci Technol. 2008;147:8-35.

31. Naumann HD, Tedeschi LO, Zeller WE, Huntley NF. The role of condensed tannins in ruminant animal production: advances, limitations and future directions. Revista Brasileira de Zootecnia. 2017:46:929-49.

32. Kim WY, Hanigan MD, Lee SJ, Lee SM, Kim DH, Hyun JH, Yeo JM, Lee SS. Effects of Cordyceps militaris on the growth of rumen microorganisms and in vitro rumen fermentation with respect to methane emissions. J Dairy Sci. 2014;97:7065-75.

33. Giang NTT, Wanapat M, Phesatcha K, Kang S. Effect of inclusion of different levels of Leucaena silage on rumen microbial population and microbial protein synthesis in dairy steers fed on rice straw. Asian-Australas J Anim Sci. 2017:30:181

34. Stern MD, Bach A, Calsamiglia S. Alternative techniques for measuring nutrient digestion in ruminants. J Anim Sci. 1997;75:2256-76.

35. Kernick BL. The effect of form of nitrogen on the efficiency of protein synthesis by rumen bacteria in continuous culture. 1991.

36. Hess HD, Monsalve LM, Lascano CE, Carulla JE, Diaz TE, Kreuzer M. Supplementation of a tropical grass diet with forage legumes and Sapindus saponaria fruits: effects on in vitro ruminal nitrogen turnover and methanogenesis. Austral J Agric Res. 2003;54:703-13.

37. Puchala R, Min BR, Goetsch AL, Sahlu T. The effect of a condensed tannin-containing forage on methane emission by goats. J Anim Sci. 2005 83:182-6.

38. AOAC. Official Methods of Analysis. 19th ed. Gaithersburg: Association of Official Analytical Chemists; 2012

39. Van Soest PV, Robertson JB, Lewis BA. Methods for dietary fiber, neutral detergent fiber, and nonstarch polysaccharides in relation to animal nutrition. J Dairy Sci. 1991;74:3583-97.
40. Burns RE. Method for estimation of tannin in grain sorghum 1. Agron J. 1971;63:511-2.

41. Wanapat M, Poungchompu O. Method for estimation of tannin by vanillinHCl method (A modified method of Burns, 1971). Department of Animal Science, Khon Kaen University, Khon Kaen, 4002. 2001.

42. Samuel M, Sagathevan S, Thomas J, Mathen G. An Hplc Method for Estimation Of volatile Fatty Acids in Ruminal Fluid. Indian J Anim Sci. 1997; 67:805-7.

43. Chen XB, Gomes MJ. Estimation of microbial protein supply to sheep and cattle based on urinary excretion of purine derivatives-An over of the technical details. International Feed Resources Unit, Rowett Reseach Institute, Bucksburn Aberdee AB2 9SB, UK (1995).

44. Valadares RFD, Broderick GA, Valadares Filho SC, Clayton MK. Effect of replacing alfalfa silage with high moisture corn on ruminal protein synthesis estimated from excretion of total purine derivatives. J Dairy Sci. 1999:82: 2686-96.

45. Galyean M. Laboratory procedure in animal nutrition research. Department of Animal and Life Science. New Mexico State University, USA 188. 1989

46. Moss AR, Jouany JP, Newbold J. Methane production by ruminants: its contribution to global warming. Annal Zootech. 2000;49:231-53.

47. Wanapat M, Gunun P, Anantasook N, Kang S. Changes of rumen pH, fermentation and microbial population as influenced by different ratios of roughage (rice straw) to concentrate in dairy steers. J Agric Sci. 2014;152: 675-85.

48. Crocker CL. Rapid determination of urea nitrogen in serum or plasma without deproteinization. Amer J Med Technol. 1967:33:361.

49. SAS (Statistical Analysis System). User's Guide: Statistic, Version 9.4th Edition. SAS Inst. Inc., Cary, (2013).

50. Steel RG, Torrie JH. Principles and procedures of statistics, a biometrical approach (No. Ed. 2). Ltd: McGraw-Hill Kogakusha; 1980.

\section{Publisher's Note}

Springer Nature remains neutral with regard to jurisdictional claims in published maps and institutional affiliations.

Ready to submit your research? Choose BMC and benefit from:

- fast, convenient online submission

- thorough peer review by experienced researchers in your field

- rapid publication on acceptance

- support for research data, including large and complex data types

- gold Open Access which fosters wider collaboration and increased citations

- maximum visibility for your research: over $100 \mathrm{M}$ website views per year

At BMC, research is always in progress.

Learn more biomedcentral.com/submissions 